
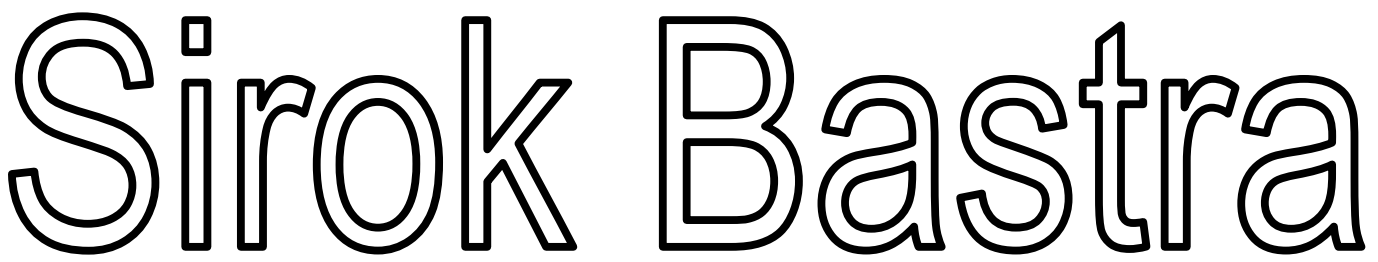

JURNAL ILMIAH KEBAHASAAN DAN KESASTRAAN

\begin{tabular}{|c|c|c|c|c|c|}
\hline $\begin{array}{c}\text { Sirok Bastra } \\
\text { Jurnal Kebahasaan dan } \\
\text { Kesastraan }\end{array}$ & Volume 2 & Nomor 2 & $\begin{array}{c}\text { Hlm. } \\
121-210\end{array}$ & $\begin{array}{l}\text { Pangkalpinang, } \\
\text { Desember 2014 }\end{array}$ & $\begin{array}{c}\text { ISSN } \\
2354-7200\end{array}$ \\
\hline
\end{tabular}

KANTOR BAHASA PROVINSI BANGKA BELITUNG 


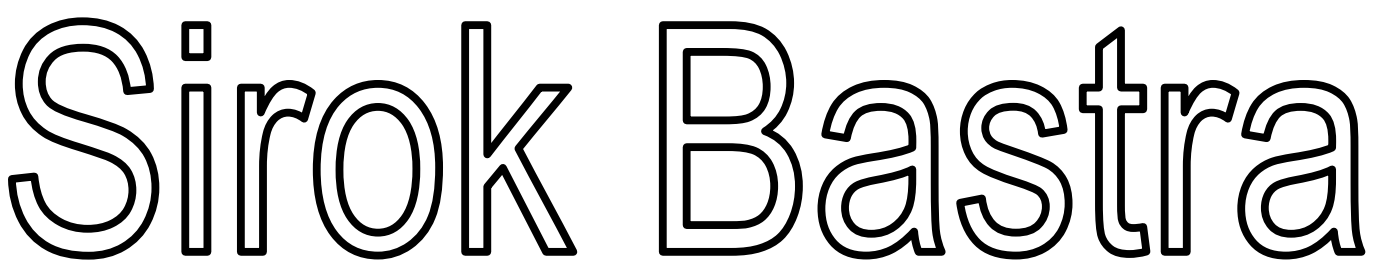

JURNAL ILMIAH KEBAHASAAN DAN KESASTRAAN

Jurnal ini merupakan wadah informasi mengenai kebahasan, kesastraan, dan pengajarannya yang memuat hasil penelitian, studi kepustakaan, dan tulisan ilmiah bidang kebahasan dan kesastraan serta pengajarannya. Sirok Bastra terbit dua kali setahun, yakni Juni dan Desember, serta terbit sejak Juni 2013.

\section{Penanggung Jawab}

Kepala Kantor Bahasa Provinsi Bangka Belitung Drs. Umar Solikhan, M.Hum.

Mitra Bestari

Prof. Dr. Agus Nuryatin, M.Hum. (Bidang Sastra dan Pengajarannya)

Prof. Amrin Saragih, Ph.D., M.A. (Bidang Bahasa dan Pengajarannya)

Dr. Felicia Nuradi Utorodewo, M.Hum. (Bidang Bahasa dan Pengajarannya)

Dr. Pujiharto, M.Hum. (Bidang Sastra dan Pengajarannya)

\section{Pemimpin Redaksi}

Rahmat Muhidin, S.S.

\section{Penyunting}

Prima Hariyanto, S.Hum.

\section{Perancang Sampul}

Feri Pristiawan, S.S.

\section{Kesekretariatan}

Khaliffitriansyah, S.Pd.

Dea Letriana Cesaria, S.Hum.

Lia Aprilina, S.Pd.

Andrian Priyatno, A.Md.

Elzam

\section{Alamat Redaksi dan Penerbit}

Kantor Bahasa Provinsi Bangka Belitung

Ruko Permata 7, Jalan Solihin G.P. Km 4, Kota Pangkalpinang, Prov. Kepulauan Bangka Belitung

Telp./Faks.: 0717-438455, Pos-el: sirokbastra@gmail.com, sirokbastra@kemdikbud.go.id

Pemuatan suatu tulisan dalam jurnal ini tidak berarti redaksi menyetujui isi tulisan tersebut. Isi tulisan menjadi tanggung jawab penulis. Tulisan telah ditinjau dan diulas oleh mitra bestari. Setiap karangan dalam jurnal ini dapat diperbanyak setelah mendapat izin tertulis dari penulis, redaksi, dan penerbit. 


\section{PENGANTAR}

Puji syukur ke hadirat Pemilik dan Pencipta semesta ini yang memiliki kuasa atas diri-Nya sendiri. Dialah Tuhan Yang Maha Esa yang telah memberikan rahmat dan hidayah-Nya sehingga Volume 2 Nomor 2 Jurnal Sirok Bastra Tahun 2014 dapat terbit tepat pada waktunya.

Pada edisi ini, dimuat sepuluh tulisan, yakni satu tulisan kebahasaan, satu tulisan pengajaran bahasa, dan delapan tulisan kesastraan. Dalam penelitiannya, Anitawati Bachtiar, Adek Dwi Oktaviantina, dan Rukmini membahas penggunaan alih kode dan campur kode pada dialog ubrug. Berdasarkan penelitian, ditemukan bentuk alih kode intern, berupa peralihan dari bahasa Jawa Serang menjadi Sunda Banten dan sebaliknya, serta alih kode metaforis dan situasional. Terdapat pula campur kode ke dalam yang berbentuk penyisipan kata pada kalimat yang diucapkan para pemain. Tujuan penggunaan alih kode dan campur kode itu adalah untuk memecah kekakuan saat pementasan, serta membangkitkan rasa humor agar penonton dapat terhibur.

Abdul Aziz melakukan penelitian yang bertujuan untuk mengupayakan peningkatan keterampilan siswa dalam menulis paragraf melalui metode inkuiri dengan menggunakan media audio pada siswa kelas $\mathrm{X}_{1}$ SMA DDI Alliritengae, Kabupaten Maros. Hasil penelitian menunjukkan bahwa metode inkuiri dengan menggunakan media audio dapat meningkatkan kemampuan menulis paragraf siswa kelas $\mathrm{X}_{1}$ SMA DDI Alliritengae, Kabupaten Maros pada tahap pelaksanaan dan tahap penilaian.

Dalam kajiannya, Tri Lia memaparkan nilai sosial dan budaya dalam cerita pendek "Sri Sumarah" karya Umar Kayam. Berdasarkan analisis, ditemukan beberapa nilai sosial budaya yang terdapat dalam cerita pendek ini, yaitu wayang dan stratifikasi sosial, masyarakat Jawa yang nrimo, sistem sapaan dalam masyarakat Jawa, mistik kejawen, masyarakat Jawa yang pembalas budi, keselarasan hidup masyarakat Jawa, dan latar politik PKI.

Dalam kajiannya, Dindin Samsudin membandingkan teka-teki (pertanyaan tradisional) yang terdapat di Provinsi Nanggroe Aceh Darussalam, yakni hiem dan yang terdapat di Provinsi Jawa Barat, yakni tatarucingan. Berdasarkan penelitian, terdapat beberapa hiem Aceh dan tatarucingan Sunda yang memiliki persamaan.

Dalam kajiannya, Kurniati membahas novel Orang-Orang Proyek karya Ahmad Tohari yang menurutnya berusaha menghadirkan sebuah realitas kemanusiaan, yakni melawan korupsi dan berbagai penyimpangan. Penulis menunjukkan bahwa di dalam novel tersebut terdapat kebenaran sosial. Karya ini memiliki sebab dan hasil kehebatan nilai artistik sebuah karya sastra (dengan dokumen sosialnya) sebagai potret kenyataan sosial.

Dalam penelitiannya, Sony Sukmawan membahas apokaliptisme sastra lisan Lereng Arjuna. Ciri-ciri yang terdapat dalam sastra lisan Lereng Arjuna dalam wujud (i) pemahlawanan tokoh mitologis dan sosok cikal bakal, trindih ukir, atau babat alas desa setempat; (ii) implikasi gagasan apokaliptik di balik latar penamaan desa, latar penamaan situs-situs purbakala, dan situs keramat alami; (iii) penamaan para-baureksa dalam mantra; serta (iv) pengungkapan apokaliptik sebagai pemulihan stabilitas alam melalui tindakan pencegahan yang persuasif.

Hestiyana membahas tema dan amanat cerita rakyat di Kecamatan Karang Intan, Kabupaten Banjar. Dalam penelitiannya, ditemukan tiga bentuk cerita rakyat, yaitu dongeng, legenda, dan mite. Cerita rakyat tersebut terdiri atas satu dongeng yang berjudul "Ular Tadung di Gunung Kiyau"; dua legenda berjudul "Asal Usul Nama Desa Karang Intan" dan "Asal Usul Nama Danau Purun"; dan satu mite berjudul "Pamandian Putri di Gunung Putra Bulu".

Dalam penelitiannya, Helmina Kastanya membahas tradisi lisan tatabuang manare dan badendang yang merupakan salah satu kekayaan sastra yang mengandung nilai estetika dalam pesta pernikahan masyarakat Pulau Ambon. Berdasarkan penelitian, bentuk tradisi lisan tatabuang manare dan badendang adalah prosesi berbalas pantun sambil menari diiringi alunan musik totobuang dan tifa. Tradisi ini berfungsi sebagai media penyatuan dua keluarga yang baru menjadi besan. Adapun nilai yang terkandung di dalamnya adalah nilai percintaan, kekeluargaan, dan sosial.

Dalam penelitiannya, Bagus Kurniawan membahas strategi pembacaan dekonstruksi karakter Arjuna sebagai lelananging jagad dalam lakon-lakon wayang purwa. Menurutnya, pemaknaan terhadap wayang masa kini mulai beragam, tidak hanya melalui dikotomi hitam-putih, tetapi juga melalui berbagai tafsir yang kemudian 
mendekonstruksi makna yang sudah mapan. Dalam tulisan ini, diuraikan strategi pembacaan secara dekonstruksi terhadap karakter Arjuna dengan menggunakan beberapa lakon wayang berbahasa Indonesia yang diterbitkan di majalah Cempala.

Mulawati mengkaji nilai karakter bangsa dalam nyanyian rakyat Muna di Provinsi Sulawesi Tenggara. Berdasarkan penelitian, unsur intrinsik nyanyian rakyat Muna menyiratkan nilai-nilai karakter bangsa seperti disiplin, selalu bekerja keras, mandiri, kreatif, dan toleransi.

Kami mengucapkan terima kasih kepada para penulis yang telah bersedia menerbitkan karya mereka pada edisi ini. Para penulis merupakan peneliti, pakar, dosen, guru, dan mahasiswa dari berbagai sekolah, perguruan tinggi, dan instansi. Terima kasih juga kami sampaikan kepada para mitra bestari yang telah memberi ulasan terhadap tulisan-tulisan yang masuk ke redaksi.

Demi memenuhi keberagaman isi dan penulis, Sirok Bastra membuka kesempatan bagi para peneliti dan penulis untuk menyampaikan hasil penelitian dan pemikiran mutakhir dalam bidang kebahasaan, kesastraan, dan pengajarannya.

Pangkalpinang, Desember 2014

\section{Tim Redaksi}




\section{UCAPAN TERIMA KASIH UNTUK MITRA BESTARI}

Redaksi Sirok Bastra mengucapkan terima kasih kepada para mitra bestari yang telah meninjau, menimbang, dan mengulas makalah-makalah yang diterbitkan dalam Sirok Bastra Volume 2 Nomor 2, edisi Desember 2014, yakni

\section{Prof. Dr. Agus Nuryatin, M.Hum.}

Bidang Sastra dan Pengajarannya

Universitas Negeri Semarang

Semarang, Jawa Tengah

Prof. Amrin Saragih, Ph.D., M.A.

Bidang Bahasa dan Pengajarannya

Universitas Negeri Medan

Medan, Sumatra Utara

\section{Dr. Felicia Nuradi Utorodewo, M.Hum.}

Bidang Bahasa dan Pengajarannya

Universitas Indonesia

Depok, Jawa Barat

\section{Dr. Pujiharto, M.Hum.}

Bidang Sastra dan Pengajarannya

Universitas Gadjah Mada

Yogyakarta, Daerah Istimewa Yogyakarta 


\section{DAFTAR ISI}

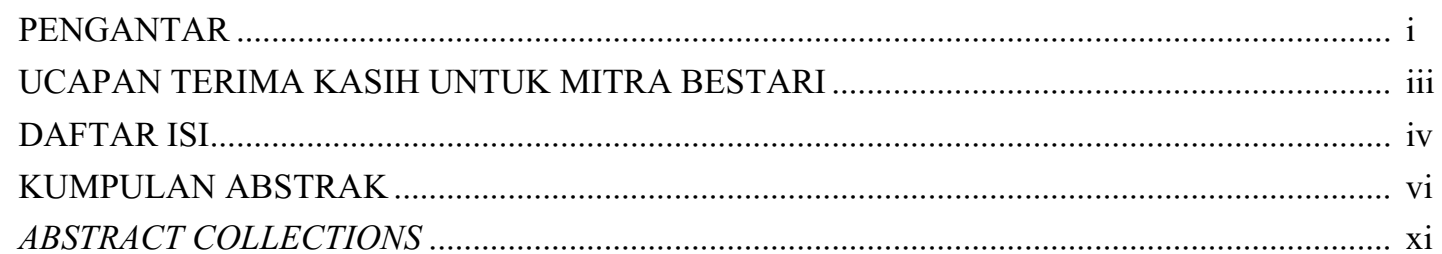

\section{UBRUG: KAJIAN SOSIOLINGUISTIK}

(Ubrug: Sociolinguistic Study)

Anitawati Bachtiar, Adek Dwi Oktaviantina, dan Rukmini $121-128$

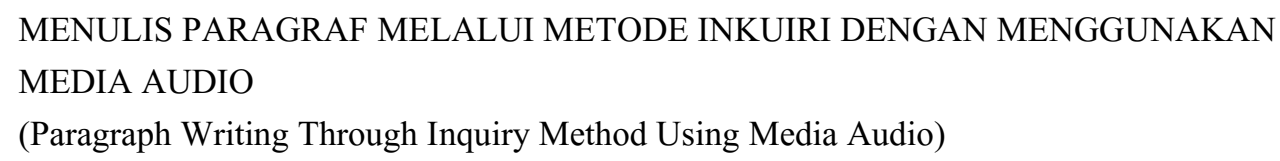

TEMA DAN AMANAT CERITA RAKYAT DI KECAMATAN KARANG INTAN, KABUPATEN BANJAR

(Theme and Message of Folklore in Karang Intan Subdistrict, Banjar Regency)

TATABUANG MANARE DAN BADENDANG DALAM PESTA PERNIKAHAN MASYARAKAT PULAU AMBON

(Tatabuang Manare and Badendang in Wedding Party of Ambon Island Society) 
MENGGUGAT ARJUNA SEBAGAI LELANANGING JAGAD: SEBUAH STRATEGI PEMBACAAN DEKONSTRUKSI KARAKTER ARJUNA DALAM LAKON-LAKON WAYANG PURWA

(Arjuna Sued as A Man of Universe: The Deconstruction of Reading Strategy for Arjuna's Character on Purwa Puppet Shows)

Bagus Kurniawan $193-200$

NILAI KARAKTER BANGSA DALAM NYANYIAN RAKYAT MUNA

(Nation Character Values in Munanese Folksong)

Mulawati $201-201$ 
Dindin Samsudin: Persamaan Bentuk Hiem Aceh dan Tataruncingan Sunda

\title{
PERSAMAAN BENTUK HIEM ACEH DAN TATARUCINGAN SUNDA
}

\section{The Similarities Form of Hiem Aceh and Tatarucingan Sunda}

\author{
Dindin Samsudin \\ Balai Bahasa Provinsi Jawa Barat \\ Jalan Sumbawa 11 Bandung, Jawa Barat 40113 \\ Pos-el: dins_samsoe75@yahoo.com
}

(diterima 14 Maret 2014, disetujui 16 Mei 2014, revisi terakhir 20 Juni 2014)

\begin{abstract}
Abstrak
Dalam kesusastraan tradisional dikenal beberapa bentuk sastra lisan, di antaranya teka-teki (pertanyaan tradisional). Dalam kehidupan masyarakat di Provinsi Nanggroe Aceh Darussalam terdapat sastra lisan yang berupa teka-teki, yaitu hiem. Sementara itu, dalam kehidupan masyarakat di Provinsi Jawa Barat terdapat juga sastra lisan yang berupa teka-teki, yaitu tatarucingan. Masalah yang dikaji dalam penelitian ini berkenaan dengan persamaan antara hiem Aceh dan tatarucingan Sunda. Penelitian ini bertujuan mendeskripsikan persamaan bentuk dan isi antara hiem Aceh dan tatarucingan Sunda. Penelitian ini menggunakan metode deskriptif analisis, yaitu metode yang dilakukan dengan cara mendeskripsikan fakta yang ada, kemudian disusul dengan analisis. Dalam penelitian ini terungkap bahwa terdapat beberapa hiem Aceh dan tatarucingan Sunda yang memiliki persamaan.
\end{abstract}

Kata Kunci: Hiem, Tatarucingan, Sunda, Aceh

\begin{abstract}
In the traditional literature there are some forms of oral literature, among them is a puzzle (the traditional question). In the life of people of Aceh province there is a form of oral literature puzzle, namely hiem. Meanwhile, in the life of the people of West of Java province there is also an oral literature in the form of puzzle, namely tatarucingan. Issues studied in this research has related to the equality between hiem of Acehnese and tatarucingan of Sundanese. This study aims to describe the similarities between the form and the content of hiem Acehnese and tatarucingan Sundanese. This study used an analysis descriptive method, a method that is done by describing the facts, and then followed by analysis. The result of this research is that there are some similarities of Acehnese hiem and Sundanese tatarucingan.
\end{abstract}

Keywords: Hiem, Tatarucingan, Sundanese, Acehnese

\section{PENDAHULUAN}

\subsection{Latar Belakang}

Dalam kesusastraan tradisional dikenal beberapa bentuk sastra lisan, di antaranya pantun, gurindam, syair, peribahasa, pepatah, dan teka-teki (pertanyaan tradisional). Teka-teki merupakan salah satu bentuk sastra lisan yang menarik karena selain dijadikan alat untuk "mengasah otak", juga dimanfaatkan sebagai hiburan di waktu senggang. Seperti diketahui, isi atau maksud yang ada dalam sebuah teka-teki tidak dikemukakan secara langsung, tetapi disembunyikan untuk diterka atau diartikan oleh pendengar atau pembacanya.
Dalam kehidupan masyarakat di Provinsi Nanggroe Aceh Darussalam terdapat sastra lisan yang berupa teka-teki, yaitu hiem. Sementara itu, dalam kehidupan masyarakat di Provinsi Jawa Barat terdapat juga sastra lisan yang berupa teka-teki, yaitu tatarucingan.

Hiem merupakan seni adu pikir dan olah kata yang berkembang dalam masyarakat Aceh. Hiem diciptakan oleh orang-orang yang cerdas (banyak akal) untuk kepentingan belajar dan mengajar (Aceh Pedia-Enslikopedia Aceh Terlengkap).

Masyarakat Aceh dalam keseharian sering kumpul bersama sanak keluarga dan kerabat untuk ber-hiem 
Dindin Samsudin: Persamaan Bentuk Hiem Aceh dan Tataruncingan Sunda

sejenak. Hiem dalam masyarakat Aceh selain digunakan sebagai media hiburan dan asah otak, juga digunakan sebagai penambah ilmu pengetahuan karena dalam hiem terkandung unsur pendidikan. Walaupun demikian, seperti umumnya sebuah tekateki, dalam hiem unsur humor tentu saja lebih dominan.

Berikut adalah contoh hiem yang ada dalam masyarakat Aceh.

(1) Bak jih sibak boh jih saboh, jiarong roh siumu masa 'pohonnya sebatang, buahnya satu, diarungi hingga seumur masa'

Jawaban: alat pembajak sawah yang terbuat dari kayu (Jakfar, Waled, 2013)

(2) Tasibu layei, taadei leuhu 'disiram layu, dijemur subur'

Jawaban: kapas (Jakfar, Waled, 2013)

Di lingkungan masyarakat Sunda juga dikenal sastra lisan yang berbentuk teka-teki dengan sebutan tatarucingan. Dalam masyarakat Sunda, tatarucingan merupakan teka-teki yang berupa tanya jawab atau dialog antara dua orang atau lebih yang mengandung unsur humor (Sulaeman, 2012).

Dalam tatarucingan, pertanyaan dan jawaban pada umumnya sekadar bercanda. Biasanya, penanya dan penjawab saling bergantian dalam melontarkan pertanyaan dan memberikan jawaban. Tatarucingan kadang-kadang juga digunakan oleh guru untuk menghidupkan suasana kelas dalam kegiatan belajar mengajar.

Berikut ini contoh tatarucingan.

1. Indungna diusapan, anaknya ditincakkan 'ibunya dibelai-belai, anaknya diinjak-injak'.

Jawaban: taraje (tangga). (Hidayat dan Darpan (2012:12)

2. Imah leutik pinuh $k u$ suluh ('rumah kecil penuh dengan kayu bakar').

Jawabannya: korek api. (Hidayat dan Darpan (2012:12)

\subsection{Masalah}

Masalah yang dikaji dalam penelitian ini berkenaan dengan persamaan antara hiem Aceh dan tatarucingan Sunda.

\subsection{Tujuan}

Penelitian ini bertujuan mendeskripsikan persamaan bentuk dan isi antara hiem Aceh dan tatarucingan Sunda.

\subsection{Manfaat}

Penelitian ini sangat bermanfaaat sebagai salah satu upaya untuk pengenalan dan pelestaraian bentuk sastra tradisional yang berupa teka-teki.

\subsection{Metode}

Penelitian ini menggunakan metode deskriptif analisis, yaitu metode yang dilakukan dengan cara mendeskripsikan fakta yang ada dan disusul dengan analisis. Dalam pelaksanaannya, metode ini dilakukan melalui empat tahap, yaitu tahap pengumpulan data, pengklasifikasian data, penganalisisan data, dan penyimpulan.

Pengumpulan data penelitian menggunakan teknik catat, yaitu membaca secara kritis bentuk-bentuk hiem Aceh dan tatarucingan Sunda. Kemudian, fenomena bentuk-bentuk persamaan hiem dan tatarucingan tersebut dicatat untuk keperluan analisis.

\section{KERANGKA TEORI}

Sastra Nusantara adalah sastra berbahasa daerah yang tumbuh dan berkembang di daerah kepulauan Nusantara (Soebadio, 1991:9). Hutomo (1991:1) mengatakan bahwa sastra lisan adalah karya yang diciptakan dan disampaikan secara lisan dengan mulut, baik di dalam suatu pertunjukkan seni, maupun di luarnya.

Teka-teki merupakan salah satu bentuk sastra lisan nusantara yang tumbuh dan berkembang dalam kehidupan masyarakat Indonesia. Badudu-Zain (1994:1454) mengatakan bahwa teka-teki adalah sesuatu berupa pertanyaan yang harus diterka, ditebak; sesuatu (hal, masalah, dan sebagainya.) yang sukar ditemukan jawabannya, atau yang sukar dipecahkan. Sementara itu, menurut Kamus Besar Bahasa Indonesia (2008:1653) teka-teki adalah 'soal dan sebagainya yang berupa kalimat (cerita, gambar, dan sebagainya) yang dikemukakan secara samarsamar, biasanya untuk permainan atau untuk pengasah pikiran; tebakan; terkaan'. 
Menurut Robert A. George dan Alan Dundes tekateki adalah ungkapan lisan tradisional yang mengandung satu atau lebih unsur pelukisan (descriptive), sepasang darinya dapat saling bertentangan dan jawabnya (referent) harus diterka (George \& Dundes, 1963:113 dalam Pattigo, 2012).

Pattigo (2012) mengungkapkan bahwa menurut Archer Taylor berdasarkan sifat hal yang digambarkan di dalam pertanyaan, teka-teki diklasifikasikan menjadi beberapa kategori umum:

1. Persamaan dengan binatang, misalnya "Ayam apa yang berbulu terbalik, bermain di kebun?" Jawaban: buah nanas

2. Persamaan dengan berbagai binatang, misalnya "Dua ekor kelinci putih keluar masuk gua, apa itu?" Jawaban: ingus di hidung seorang anak kecil yang sedang pilek.

3. Persamaan dengan manusia, misalnya "Nenek jatuh bersorak, apa itu?" Jawaban: daun kelapa kering yang rontok, waktu jatuh ke bumi menimbulkan suara keras.

4. Persamaan dengan beberapa orang, misalnya "Anaknya bersarung induknya telanjang, apakah itu?" Jawaban: rebung dan bambu.

5. Persamaan dengan benda, misalnya "Mas apa yang banyak di ekspor ke Lampung?" Jawaban: mas Jawa.

Selain kelima kategori umum itu, menurut Archer Taylor masih ada empat kategori lagi yang bukan berdasarkan sifat hal yang digambarkan di dalam pertanyaan, melainkan karena tambahan keterangan yang lebih mendetail. Keempat kategori itu adalah sebagai berikut (Pattigo, 2012).

1. Pertambahan keterangan perumpamaan, misalnya "Bulat bagaikan simpai, dalam bagaikan cangkir, seluruh sapi jantan raja tidak dapat menariknya." Jawaban: sebuah sumur.

2. Pertambahan keterangan pada bentuk dan fungsi, misalnya "Tambal sini tambal sana, tetapi tidak ada bekas jahitannya." Jawaban: sayur kubis.

3. Pertambahan keterangan pada warna, misalnya "Dilempar ke atas hijau, jatuh ke bawah merah." Jawaban: semangka.
4. Pertambahan dalam tindakan, misalnya "Buah apa yang dibuang luarnya, dimasak dalamnya, dimakan luarnya, dan dibuang dalamnya?" Jawabnya: buah jagung.

Teka-teki berkembang subur dalam masyarakat terutama pada masa lalu. Dalam kehidupan masyarakat, teka-teki dapat digunakan sebagai penguji kepandaian seseorang dan sebagai penghibur pada waktu senggang. Selain itu, teka-teki juga kerap dimunculkan sebagai pelengkap dalam kesenian tradisional. Bastra (2012) mengungkapkan bahwa di dalam kehidupan masyarakat, teka-teki memiliki fungsi sebagai berikut.

(1) menyampaikan pendidikan

(2) menghibur

(3) menggoda.

Teka-teki dalam masyarakat Aceh dikenal dengan istilah hiem. Ameer Hamzah, seorang sastrawan Aceh, mengatakan bahwa hiem adalah bagian dari proses berpikir dan jawaban dari sebuah hiem merupakan buah kecerdasan seseorang. Hiem diciptakan oleh orang-orang yang cerdas (banyak akal) untuk kepentingan belajar dan mengajar. Oleh karena itu, menciptakan hiem tidak sekadar untuk mencari-cari kelemahan orang lain. Dalam sebuah ciptaan hiem yang berkualitas mengandung banyak unsur ilmu yang perlu dipadukan di dalamnya, antara lain ilmu agama, ilmu jiwa, tasauf, logika (manthek), ilmu budaya, dan lain-lain bila diperlukan (Aliansi Sastrawan Aceh, 2009).

Jika dilihat dari segi bentuk, hiem terdiri atas dua bagian: kulit (pertanyaan) dan isi (jawaban). Kulit biasanya berupa kalimat, sedangkan isi pada umumnya berupa kata. Beberapa contoh hiem yang sangat merakyat di antaranya sebagai berikut.

(1) On jih sion bak jih sion, meunan tiep-tiep thon si umu donya 'daunnya selembar, batangnya sebatang, begitulah sepanjang masa'.

Jawaban: Aweeuk sudok 'centong nasi/sendok nasi'. (Aceh Pedia-Enslikopedia Aceh Terlengkap, 2009).

(2) Soboh cicem jipo u gunong, sayeuep dua gaki jih enam 'seekor burung terbang ke gunung, sayapnya dua, kakinya enam'. 
Jawaban: lalat. (Aceh Pedia-Enslikopedia Aceh Terlengkap, 2009).

(3) Ma keuh ruhieb, ku keueh reuhoub ('ibunya peyot, bapaknya ringsek'). Jawaban: boh kruet (jeruk purut). (Aceh Pedia-Enslikopedia Aceh Terlengkap, 2009).

Di lingkungan masyarakat Sunda dikenal sastra lisan yang berbentuk teka-teki dengan sebutan tatarucingan. Awalnya, tatarucingan disebut dengan tuturucingan yang berasal dari kata turucing. Dalam Kamus Basa Sunda, R.A Danadibrata (2009:718) disebutkan bahwa turucing berarti 'rangkaian perkataan yang harus dicari artinya'. Sementara itu, tuturucingan berarti 'permainan mengeluarkan ruparupa tarucing'. Akan tetapi, kapan dan mengapa kata turucing berubah menjadi tarucing tidak ada satu sumber pun yang dapat menelusurinya.

Hidayat dan Darpan (2012:9) mengungkapkan bahwa pada umumnya tatarucingan diungkapkan sambil bercanda dalam bentuk saling tanya jawab antara dua orang atau lebih. Dengan demikian, dalam tatarucingan, pertanyaan dan jawaban pada umumnya sekadar bercanda. Biasanya, penanya dan penjawab saling bergantian dalam melontarkan pertanyaan dan memberikan jawaban.

Tatarucingan dari waktu ke waktu terus bertambah dan beragam versi disesuaikan dengan perkembangan zaman. Dahulu pertanyaan dan jawaban dalam tatarucingan terikat dengan logika. Akan tetapi, bentuk tatarucingan sekarang lebih longgar karena si pembuat tatarucingan zaman sekarang kadang-kadang mengesampingkan unsur logika (Hidayat dan Darpan, 2012:10).

Berdasarkan bentuknya, tatarucingan terdiri atas dua bagian: kulit (pertanyaan) dan isi (jawaban). Kulit biasanya berupa kalimat, sedangkan isi pada umumnya berupa kata. Berikut ini beberapa contoh tatarucingan.

(1) Awakna ditincak, beuheungna dicekek 'badannya diinjak, lehernya dicekik'. Jawaban: sendal 'sandal' (Hidayat dan Darpan, 2012:11)

(2) Budak dugul loba kutu 'anak botak banyak kutu'. Jawaban: kueh onde 'kue onde-onde' (Hidayat dan Darpan, 2012:11)
(3) Oray hejo panonna loba 'ular hijau banyak matanya'. Jawaban: peuteuy 'petai' (Hidayat dan Darpan, 2012:12)

Berdasarkan contoh tersebut, tatarucingan dan hiem memiliki persamaan bentuk, yaitu terdiri atas dua bagian: kulit (pertanyaan) dan isi (jawaban). Bagian kulit biasanya berupa kalimat dan bagian isi umumnya berupa kata.

\section{HASIL DAN PEMBAHASAN}

Setelah penulis amati, selain memiliki persamaan bentuk, beberapa hiem Aceh dan tatarucingan Sunda juga memiliki persamaan dalam kalimat pemaparan kulit (pertanyaan) dan persamaan dari segi isi (jawaban). Selain itu, terdapat juga hiem dan tatarucingan yang hanya memiliki persamaan isi, tetapi berbeda dalam kalimat pemaparan kulit.

\subsection{Persamaan Bentuk Kulit dan Isi}

Hiem dan tatarucingan berikut ini memiliki persamaan kalimat dalam pemaparan kulit dan memiliki persamaan bentuk isi.

\subsubsection{Persamaan Hiem dan Tatarucingan yang Berisi (Jawaban) "Bayangan"}

a. Hiem: Tajak pih jijak, taduek pih jiduek, ta plueng pih jiplueng 'kita pergi dia pergi, kita duduk dia pun duduk, kita lari dia pun lari'.

b. Tatarucingan: Diudag lumpat, didagoan cicing 'dikejar lari, ditunggu diam' (Gunawan, 2010)

Dalam kalimat pemaparannya, hiem dan tatarucingan tersebut sama-sama menggunakan kata lari dalam pertanyaan. Jika dicermati, kalimat pemaparan kulit hiem dan tatarucingan tersebut juga memiliki persamaan lain yaitu dari segi makna 'tidak bergerak'. Hiem (a) menggunakan kata duduk, sedangkan tatarucingan (b) menggunakan kata diam. Kedua kata tersebut menunjukkan makna 'tidak bergerak'. Dengan demikian, hiem dan tatarucingan tersebut secara tersirat memiliki persamaan dalam kalimat penyampaian pemaparan kulit.

\subsubsection{Persamaan Hiem dan Tatarucingan yang Berisi (Jawaban) "Becak"}

a. Hiem: Rumoh geut na geuduek di lua 'rumah bagus, duduk di luar'. 
b. Tatarucingan: Pribumi di luar ari semah di jero 'tuan rumah di luar, tamu di dalam' (Gunawan, 2010)

Dalam kalimat pemaparannya, hiem dan tatarucingan tersebut menyamakan becak dengan rumah. Becak dianggap sebagai rumah karena becak memiliki atap dan kursi (tempat duduk penumpang) sama seperti rumah. Hiem (a) mengatakan (tuan rumah) duduk di luar karena penarik becak sebagai pemilik tidak mendiami rumah (becak). Sementara itu, tatarucingan (b) juga menyamakan sopir becak sebagai tuan rumah dan menyamakan penumpang sebagai tamu. Dengan demikian, selain memiliki persamaan isi, hiem (a) dan tatarucingan (b) secara tersirat memiliki persamaan dalam kalimat penyampaian pelukisan kulit dengan mengiaskan becak sebagai rumah dan tukang becak sebagai tuan rumah (pemilik rumah).

\subsubsection{Persamaan Hiem dan Tatarucingan yang Berisi (Jawaban) "Telinga"}

a. Hiem: Tamap jitheun, tang ieng jiplueng 'dipegang jinak, dipandang lari'.

b. Tatarucingan: Dicabak aya dilieuk euweuh 'dipegang ada, dilihat tidak ada' (Gunawan, 2010). Hiem (a) dan tatarucingan (b) memiliki persamaan makna kalimat pada pelukisan kulit. Hiem (a) menggunakan bentuk dipegang jinak yang memiliki persamaan makna dengan dipegang ada dalam tatarucingan (b). Kemudian, Hiem (a) menggunakan bentuk dipandang lari yang juga memiliki persamaan makna dengan dilihat tidak ada dalam tatarucingan (b).

\subsubsection{Persamaan Hiem dan Tatarucingan yang Berisi (Jawaban) "Rokok (Merokok)"}

a. Hiem: Ta ceupet bak iku hu aneuk mata 'dipijit ekornya, merah biji matanya' (Pusat Humor Aceh). Hiem ini membandingkan rokok seolah mempunyai ekor seperti binatang. Hiem ini mengatakan binatang itu dipijit ekornya karena orang yang merokok biasanya memijit (memegang) rokok bagian ujung (ekor). Kemudian, hiem ini mengatakan binatang itu merah biji matanya karena bara rokok yang sedang menyala warnanya merah.

b. Tatarucingan: Digegel huluna, beak buntutna 'digigit kepalanya, habis ekornya' (Abdulrohman, 2012). Tatarucingan ini juga membandingkan rokok dengan binatang. Tatarucingan ini mengatakan binatang itu digigit kepalanya karena orang yang merokok pasti menggigit (memasukan ke dalam mulut) bagian atas rokok yang dianggap kepalanya. Kemudian, tatarucingan ini mengatakan binatang itu habis ekornya karena yang pertama habis ketika sedang merokok adalah bagian ujungnya, sedangkan kepalanya tidak akan habis walaupun dimakan.

Jika dicermati, hiem (a) dan tatarucingan (b) tersebut secara tersirat memiliki persamaan makna kalimat dalam penyampaian pelukisan kulit dengan cara mengiaskan rokok seperti binatang yang memiliki ekor, kepala, dan mata.

\subsubsection{Persamaan Hiem dan Tatarucingan yang Berisi (Jawaban) "Buah pisang"}

a. Hiem: Plak geusilak plak geupantak 'plak dikupas, plak disantap' (Pusat Humor Aceh)

b. Tatarucingan: Dibuka bajuna, didahar eusina 'dibuka bajunya, dimakan isinya'.

Hiem (a) tidak mengiaskan sesuatu dengan benda lain. Sementara itu, tatarucingan (b) membandingkan pisang dengan badan karena pisang memiliki baju (kulitnya). Akan tetapi, secara tersirat, hiem (a) dan tatarucingan (b) memiliki persamaan makna dalam kalimat penyampaian pelukisan kulit. Hiem (a) menggunakan kata dikupas yang memiliki persamaan makna dengan dibuka dalam tatarucingan (b). Selain itu, hiem (a) juga menggunakan kata disantap yang memiliki persamaan makna dengan dimakan dalam tatarucingan (b).

\subsubsection{Persamaan Hiem dan Tatarucingan yang Berisi (Jawaban) "Kereta Api"}

a. Hiem: Mak ceumeucop, aneuk dimoe, yah ji phib rukok 'ibu menjahit, anak menangis, ayahnya mengisap rokok' (Isa, 2009). 
b. Tatarucingan: Bapana udud, indungna nyeuseuh, anakna ceurik 'bapaknya merokok, ibunya mencuci, anaknya menangis' (Sulaeman, 2012).

Hiem (a) dan tatarucingan (b) tersebut menyamakan kereta api dengan aktivitas dalam sebuah keluarga yang terdiri atas ayah, ibu, dan anak. Kereta api dianggap sebagai aktivitas sebuah keluarga karena ketika sebuah kereta api berjalan akan mengeluarkan bunyi, mengeluarkan suara, dan mengeluarkan asap. Hiem (a) mengatakan ibu menjahit karena bunyi roda kereta api ketika melintas di rel akan mengeluarkan suara seperti seseorang yang sedang menjahit. Kemudian, hiem (a) mengatakan anak menangis karena suara klakson atau terompet dari kereta api seperi bunyi anak yang sedang menangis. Hiem (a) juga mengatakan bapaknya merokok karena asap yang keluar dari cerobong kereta api sama seperti seseorang yang sedang merokok.

Tatarucingan (b) menyamakan kereta api dengan aktivitas dalam sebuah keluarga yang terdiri atas ayah, ibu, dan anak. Tatarucingan daam (b) juga mengatakan bapak merokok dan anak menangis untuk menunjukkan asap dan bunyi klakson dari kereta api. Akan tetapi, untuk menunjukkan bunyi roda kereta, tatarucingan menyebutnya dengan ibu mencuci, bukan ibu menjahi" seperti apa yang dikatakan dalam hiem.

Berdasarkan hal tersebut, selain memiliki persamaan isi, hiem (a) dan tatarucingan (b) secara tersirat memiliki persamaan dalam penyampaian pelukisan kulit dengan mengiaskan becak sebagai rumah dan tukang becak sebagai tuan rumah (pemilik rumah).

\subsection{Persamaan Isi tetapi Berbeda Kulit}

Di samping memiliki persamaan dalam kalimat pemaparan kulit dan isi, terdapat juga beberapa hiem Aceh dan tatrucingan Sunda yang memiliki persamaan isi, tetapi berbeda dalam pelukisan kulit.

\subsubsection{Persamaan Hiem dan Tatarucingan yang Berisi (Jawaban) "Buah nanas"}

a. Hiem: Dara baro duk lam pageu 'pengantin duduk di dalam pagar'.
Berdasarkan sifat yang digambarkan dalam pertanyaan, kalimat pemaparan kulit dalam hiem ini menyamakan sesuatu dengan manusia. Hiem ini menyamakan buah nanas dengan pengantin yang duduk di dalam pagar. Nanas diibaratkan pengantin karena memiliki mahkota/sanggul seperti yang sering dipakai oleh pengantin. Kemudian, kiasan duduk di dalam pagar karena masyarakat Aceh biasanya menanam nanas di pinggir kebun sebagai pagar.

b. Tatarucingan: Hayam rintit nonggeng ka langit 'ayam rintit menungging ke langit' (Sulaeman, 2012).

Berdasarkan sifat yang digambarkan dalam pertanyaan, kalimat pemaparan kulit dalam tatarucingan ini menyamakan sesuatu dengan binatang. Tatarucingan ini menyamakan buah nanas dengan ayam rintit (ayam yang bulunya terbalik). Nanas dibandingkan seperti ayam rintit karena kulit buah nanas tidak rata, sama seperti bulu ayam rintit. Nanas dikatakan menungging ke langit karena daun nanas terletak di atas diibaratkan ekor ayam yang sedang menungging.

\subsubsection{Persamaan Hiem dan Tatarucingan yang Berisi (Jawaban) "Kentut"}

a. Hiem: Alue yang ji timbak hidong nyang keunong 'parit yang ditembak, hidung yang kena' (Isa, 2009).

Kalimat pemaparan kulit dalam hiem ini menggunakan penambahan keterangan yang lebih mendetail. Hiem (a) mengatakan parit yang ditembak sebagai persamaan dari bunyi kentut. Hiem juga mengatakan hidung yang kena karena ketika kentut yang pertama merasakan adalah hidung

b. Tatarucingan: Kadenge sorana, kaambu bauna, tapi teu katingali wujudna 'terdengar suaranya, tercium baunya, tapi tidak terlihat wujudnya'.

Kalimat pemaparan kulit dalam hiem ini menyamakan sesuatu dengan makhluk hidup. Tatarucingan (b) mengibaratkan kentut sebagai makhluk hidup. Tatarucingan ini mengatakan makhluk itu mengeluarkan suara karena kita mendengar suaranya. Kemudian, tatarucingan ini mengatakan makhluk itu menimbulkan bau karena kita mencium baunya. Selanjutnya, tatarucingan ini 
Dindin Samsudin: Persamaan Bentuk Hiem Aceh dan Tataruncingan Sunda

mengatakan makhluk itu tidak terlihat wujudnya karena kita memang tidak dapat melihat wujud dari kentut.

\section{PENUTUP}

\subsection{Simpulan}

Berdasarkan bahasan sebelumnya, dapat dilihat bahwa terdapat beberapa tatarucingan di masyarakat Sunda dan hiem di masyarakat Aceh yang memiliki

Tabel 1

\begin{tabular}{|l|l|l|l|}
\hline No. & $\begin{array}{c}\text { Isi (Jawaban) } \\
\text { Hiem dan } \\
\text { Tatarucingan }\end{array}$ & \multicolumn{1}{|c|}{ Kulit (Pertanyaan) Hiem } & \multicolumn{1}{|c|}{ Kulit (Pertanyaan) Tatarucingan } \\
\hline 1. & Bayangan & $\begin{array}{l}\text { Tajak pih jijak, taduek pih jiduek, ta plueng } \\
\text { pih jiplueng 'kita pergi dia pergi, kita duduk } \\
\text { dia pun duduk, kita lari dia pun lari' }\end{array}$ & $\begin{array}{l}\text { Diudag lumpat, didagoan cicing } \\
\text { 'dikejar lari, ditunggu diam' }\end{array}$ \\
\hline 2. & Becak & $\begin{array}{l}\text { Rumoh geut na geuduek di lua 'rumah } \\
\text { bagus, duduk di luar' }\end{array}$ & $\begin{array}{l}\text { Pribumi di luar ari semah di jero 'tuan } \\
\text { rumah di luar, tamu di dalam' }\end{array}$ \\
\hline 3. & Telinga & $\begin{array}{l}\text { Tamap jitheun, tang ieng jiplueng 'dipegang } \\
\text { jinak, dipandang lari' }\end{array}$ & $\begin{array}{l}\text { Dicabak aya dilieuk euweuh 'dipegang } \\
\text { ada, dilihat tidak ada' }\end{array}$ \\
\hline 4. & $\begin{array}{l}\text { Rokok } \\
\text { (Merokok) }\end{array}$ & $\begin{array}{l}\text { Ta ceupet bak iku hu aneuk mata 'dipijit } \\
\text { ekornya, merah biji matanya' }\end{array}$ & $\begin{array}{l}\text { Digegel huluna, beak buntutna 'digigit } \\
\text { kepalanya, habis ekornya' }\end{array}$ \\
\hline 5. & Buah Pisang & $\begin{array}{l}\text { Plak geusilak plak geupantak'plak dikupas, } \\
\text { plak disantap' }\end{array}$ & $\begin{array}{l}\text { Dibuka bajuna, didahar eusina 'dibuka } \\
\text { bajunya, dimakan isinya' }\end{array}$ \\
\hline Kereta Api & $\begin{array}{l}\text { Mak ceumeucop, aneuk dimoe, yah ji phib } \\
\text { rukok 'ibu menjahit, anak menangis, } \\
\text { ayahnya mengisap rokok' }\end{array}$ & $\begin{array}{l}\text { Bapana udud, indungna nyeuseuh, } \\
\text { anakna ceurik 'bapaknya merokok, } \\
\text { ibunya mencuci, anaknya menangis' }\end{array}$ \\
\hline
\end{tabular}

Beberapa hiem dan tatarucingan yang memiliki persamaan "isi, tetapi berbeda dalam kulit dapat dilihat dalam tabel berikut ini.

Tabel 2

\begin{tabular}{|l|l|l|l|}
\hline No. & $\begin{array}{c}\text { Isi (Jawaban) } \\
\text { Hiem dan } \\
\text { Tatarucingan }\end{array}$ & \multicolumn{1}{|c|}{ Kulit (Pertanyaan) Hiem } & Kulit (Pertanyaan) Tatarucingan \\
\hline 1. & Buah Nanas & $\begin{array}{l}\text { Dara baro duk lam pageu 'pengantin duduk } \\
\text { di dalam pagar' }\end{array}$ & $\begin{array}{l}\text { Hayam rintit nonggeng ka langit } \\
\text { 'ayam rintit menungging ke langit' }\end{array}$ \\
\hline 2. & Kentut & $\begin{array}{l}\text { Alue yang ji timbak hidong nyang keunong } \\
\text { 'parit yang ditembak, hidung yang kena' }\end{array}$ & $\begin{array}{l}\text { Kadenge sorana, kaambu bauna, tapi } \\
\text { teu katingali wujudna 'terdengar } \\
\text { suaranya, tercium baunya, tapi tidak } \\
\text { terlihat wujudnya' }\end{array}$ \\
\hline
\end{tabular}

\subsection{Saran}

Sastra lisan tradisional di Nusantara yang berupa teka-teki mungkin memiliki persamaan di setiap daerah. Akan tetapi, tentu saja perlu penelitian lebih persamaan isi (jawaban), tetapi berbeda dalam kalimat pelukisan kulit. Selain memiliki persamaan isi (jawaban), terdapat juga hiem dan tatarucingan yang secara garis besar memiliki persamaan dalam kalimat penyampaian pelukisan kulit (pertanyaan).

Beberapa hiem dan tatarucingan yang memiliki persamaan kulit dan isi dapat dilihat dalam tabel berikut. 
Dindin Samsudin: Persamaan Bentuk Hiem Aceh dan Tataruncingan Sunda

Keberadaan teka-teki saat ini tidaklah seindah dulu. Hal ini terjadi karena perkembangan zaman menyebabkan semakin longgarnya adat dan kebiasaan dalam masyarakat. Generasi muda sekarang hampir tidak mengetahui dan seperti kurang peduli dengan keberadaan teka-teki sehingga keberadaan teka-teki semakin menghilang di masyarakat. Akibatnya, pemasyarakatan teka-teki semakin menurun.

Teka-teki merupakan salah satu bentuk sastra lisan. Walaupun berbentuk sastra lisan, teka-teki perlu diinventarisasi dan dibukukan agar keberadaan teka-teki tetap terjaga. Jika teka-teki tidak dibukukan, lambat laun salah satu sastra lisan ini akan semakin hilang dalam kehidupan masyarakat. Oleh karena itu, upaya penginventarisan dan pembukuan teka-teki perlu terus dilakukan. Kita sebagai pencinta sastra Nusantara dan pewaris budaya bangsa harus segera melakukan pelestarian keberadaan kedua bentuk teka-teki ini.

\section{DAFTAR PUSTAKA}

Abdulrohman, Cucu. "Tatarucingan Urang Sunda," dalam http://warungbukumaya.blogspot.com/2012/11/tatarucingan-urang-sunda.html, diakses 18 Februari 2014.

Aceh Pedia-Enslikopedia Aceh Terlengkap. 2009. "Ensiklopedia Aceh Terlengkap,” dalam http://acehpedia.org/Hiem, diakses 16 Febuari 2014.

Aliansi Sastrawan Aceh. 2009.“Hiem: Warisan Aceh yang Mengandung Nilai Agama,” dalamhttp://aliansisastrawanaceh.wordpress.com/2009/08/24/hiem-warisan-aceh-yang-mengandung-nilaiagama/, diakses 6 Februari 2014.

Badudu-Zain. 1994. Kamus Umum Bahasa Indonesia. Jakarta: Pustaka Sinar Harapan.

Bastra, Chuz. 2012. “Sastra Daerah 'Teka-Teki’ Bugis,” dalam http://chuzbastra.blogspot.com/2012/05/sastradaerah-teka-teki-bugis.html, diakses 18 Februari 2014.

Danadibrata, R.A. 2009. Kamus Basa Sunda. Bandung: Kiblat.

Departemen Pendidikan Nasional. 2008. Kamus Besar Bahasa Indonesia. Jakarta: Balai Pustaka.

Gunawan, Gun Gun. 2010, “Kumpulan Tatarucingan,” dalam http://www.putragaluh.web.id/blog/show/kumpulan-tatarucingan.html\#.UvMBoKJe_IU, diakses 18 Februari 2014

Hidayat, Rahmat Taufik dan Darpan. 2012. Tatarucingan Urang Sunda. Bandung: Kiblat.

Hutomo, Suripan Sadi. 1991. Mutiara yang Terlupakan. Pengantar Studi Sastra Lisan. Jawa Timur: HISKI.

Isa, Muhammad Taufik. 2009., "Hiem Aceh,” dalam http://akhitaufiq.blogspot.com/2009_01_25_archive.html, diakses 3 Maret 2014.

Jakfar, Waled. 2013. "Hiem/Teka-Teki dan Jawabannya," dalam http://acehnationalpost.com/11/acehupdate/1082-hiem-teka-teki-jawabannya-3.html, diakses 18 Februari 2014.

Pattigo, Susri. 2012. “Teka-Teki," http://ekstensibastra.blogspot.com/2012/05/teka-teki_27.html, diakses 18 Februari 2014. 
Dindin Samsudin: Persamaan Bentuk Hiem Aceh dan Tataruncingan Sunda

Pusat Humor Aceh. 2010. "Hiem," dalam https://www.facebook.com/PUSATHUMORACEH/posts/125418220854925, diakses 28 Februari 2014.

Soebadio, Haryati. 1991. "Telaah Sastra dalam Kemajuan Bangsa,” dalam Ilmu-Ilmu Humaniora. Yogyakarta: Gadjah Mada University Press.

Sulaeman, Asep. 2012. "Conto Tatarucingan Tradisional Urang Sunda Keur Heuruy," dalam http://kangasepsule.blogspot.com/2012/12/conto-tatarucingan-tradisional-urang.html, diakses 7 Februari 2014. 
Dindin Samsudin: Persamaan Bentuk Hiem Aceh dan Tataruncingan Sunda 